\title{
Women Images in D. H. Lawrence's Short Stories
}

\author{
Xinyu Yang,
}

\author{
${ }^{1}$ School of Foreign Languages, Huzhou University, Huzhou, Zhejiang, China \\ *Corresponding author. Email: y68z69@zjhu.edu.cn
}

\begin{abstract}
David Herbert Lawrence is an important British novelist in the twentieth century and is regard as a man of genius. His greatness lies not only in his exploration in the bisexual relationship, but more in his depiction of women images concerning their nature and future. His attitude towards women is always the focus of argument. Some regard him as a male chauvinist while some regard him as a feminist colleague. This paper is to analyze Lawrence's attitude towards women in a developmental angle. Lawrence's exploration in women's nature and future can be divided into three stages. The characterization of women images in each stage is closely related to Lawrence's attitude toward women. The process that Lawrence creates his women images is also the process that he explores their aspiration and pursuit, and the process that Lawrence changes his attitude towards women.
\end{abstract}

Keywords: D.H. Lawrence, short stories, women images

\section{INTRODUCTION}

What role should a woman act in the society? What's the value of the existence of a woman? What do women want? These questions have been asked and answered for numerous times in literary works. Writers give various opinions.

A typical answer is given by the twentieth century British novelist - D. H. Lawrence, who wrote a great number of fictions about women, such as Woman in Love, The Rainbow and Lady Chatterley's Lover, which not only disclose his ideal woman's aspiration and pursuit, but also reflects his attitude towards woman.

Just as one's thought has a close relationship with his life experience, Lawrence's "life experience inevitably impacts his literature" ${ }^{1}$.

D. H. Lawrence was born on September 11th, 1885 , in a mining village in Nottinghamshire, England. His father was an illiterate coal miner, his mother a genteel schoolteacher who determined to lift her children out of working class. His parents' unhappy marriage made his mother put all her hope and care on her children. After his brother's death, Lawrence became his mother's sole spiritual ballast. Mother's strong emotion claims on him influenced the relationship between Lawrence and his girlfriends. He once fell in love with Jessie Chambers and even engaged with Louis Burrows,

\footnotetext{
Keith Saag, Lawrence's Life, Trans, Gao Wanlong \& Wangjianqi, Jinan: Shandong Friendship Books, 1989, p77.
}

but owing to his mother's envy and disapproval, he finally broke up with them. Lawrence completed his studies at University College, Nottingham in 1908 and taught for a few years at a school. In 1912 he left teaching to devote his whole life to writing career. In the same year, he ran away with a married woman Frieda Von Richthofen, sister of the famous German World War I flying ace and wife of Lawrence's French professor at Nottingham.

Lawrence's attitude towards woman has been a focus of discussion for a long time. Some critics regard him as a male chauvinism while some consider him as a feminist colleague.

The feminist case against Lawrence was first put at some length by John Middleton Murry in Son of Woman. It is from Murry's account that the caricature of Lawrence as the quaky-voiced, hysterical, important prophet of virility derives, and Murry who construed Lawrence's attitude towards woman as a function of his precarious, "hypersensitive masculinity". ${ }^{2}$

To annihilate the female insatiably demanding physical satisfaction from the man who cannot give it her - the female who has thus annihilated him - this is Lawrence's desire. To make her subject again, to reestablish his own manhood - this is the secret purpose of Women in Love. In imagination, he has his desire. He creates a sexual mystery beyond the phallic, wherein he is the lord; and he

\footnotetext{
John Middleton Murry, Son of Woman, London: Jonathan Cape, 1931, p72.
} 
makes the woman acknowledge the existence of this ultra-phallic realm, and his own lordship in it. ${ }^{3}$

Murry's approach informs much subsequent feminist criticism of Lawrence, including the two classic accounts in Simone de Beauvior's The Second Sex and Kate Millett's Sexual Politics.

Apart from many critics, feminist appreciations of Lawrence have not been lacking. After the appearance of Murry's Son of Woman, Anais Nin published D.H. Lawrence: An Unprofessional Study. According to Nin, Lawrence had "a complete realization of the feelings of women. In fact, very often he wrote as a woman would write...It is the first time that a man has so wholly and completely expressed woman accurately." ${ }^{4}$

Even Lawrence himself once declared his female stand about his lifelong literature creation in a letter on June 2nd, 1914:

I think the only resource of art, revivifying it, is to make it more the joint work of woman and man. I think the only thing to do, is for man to have courage to draw nearer to women, expose themselves to them, and be altered by them, and for women to admit and accept them.

Some people noticed that Lawrence's attitude towards woman is not like what the critics said above. There is a close relationship between Lawrence's attitude towards woman and the feminism movement. With the development of feminist movement, women's statue in family and society changed, Lawrence's attitude towards them changed

Lawrence's literary career spanned one of the most crucial periods in history. That is the feminist movement. The years before the First World War were characterized by intense feminist activities. The war itself is a watershed for women in virtually all aspect of life. During the war, because lots of men leave their hometown for the war, women have to take over the responsibilities of supporting their family and producing material wealth to feed the army. At that time women were allowed to go out to work, gradually they became economically independent. And after the war women became an important part of the society, since the number of men was greatly reduced by the war. With the improvement in social status, women want to get

\footnotetext{
3 Ibid., 118.

4 Anais Nin, D.H. Lawrence: An Unprofessinal Study (Paris: Edward W.Titus, 1932), 66-7 and 70.

Carol Dix, D.H .Lawrence and Women (London: Macmillan Press, 1980), 2.
}

more rights. At that time feminism movement became flourishing. They got more freedom and finally they got the vote right.

It is undeniable that women became more and more important in both family and society. And the women images in Lawrence's short stories perfectly reflect this change. The women images that Lawrence created reveal Lawrence's attitude towards women. It is obvious that the women images created by Lawrence before the war, during the war and after the war are essentially different. In different periods they have different qualities and fates.

\section{WOMEN IMAGES BEFORE THE WAR}

The first stage of Lawrence's art creation is from the beginning of the twentieth century to the outbreak of the First World War. In this period, Lawrence created some famous short stories such as Odour of Chrysanthemums, Daughters of the Vicar, and The Prussian Officer, which show people moving from a communal world, in which they battle against poverty, class prejudice, and natural disaster, to a more independent existence, full of potential for both self-fulfillment and selfdestruction. These short stories celebrate the vitality that is fundamental in Lawrence's vision of life, and demonstrate the diversity of interests, narrative power, and vivid sense of place and character that distinguish the works of an acknowledged master in the genre. Readers can gain insight into Lawrence's serious study into women's position in the society at that time and have a scan of woman's living status in the early $20^{\text {th }}$ century.

During this period Mrs. Pankhurst's Women's Social and Political Union was founded and began to function. Demonstrations of suffragettes were common in London in those years when Lawrence lived in Croydon as a teacher. He could not help but be exposed to this intellectual furor. These were the years of Lawrence's youth and the social background of the composition of his early works, so the extent to which the suffrage movement impinged on his early life is worth noting.

Some of Lawrence's heroines in this period, such as Mrs. Morel in Sons and Lovers and Elizabeth Bates in Odour of Chrysanthemums are usually regarded as feminists.

They are disappointed with their husbands, put all their love on their children and family, and all want to dominate their husband. Lawrence concentrates most of his attention on the dominant position of the women. Originally he intends to find a way out for society from the dominance and 
possessiveness of the women, but it turns out a destructive consequence. ${ }^{6}$

This is closely related to Lawrence's own life experience. As a sensitive man, the relationship with the women around him undoubtedly influences his attitude towards woman. In this period, he was surrounded by his mother Mrs. Lawrence and his girlfriend Jessie.

Odour of Chrysanthemums is considered as a typical short story in Lawrence's early creation. And the heroine Mrs. Bates is regarded as a representative woman image in Lawrence's early works.

The story begins with the description of the sights and sounds of a bleak mining village at the end of the mine's afternoon shift. Mrs. Bates calls her son, John, in for the evening meal and provides a light snack for her father, a train driver, while chiding her daughter, Annie, about being late from school. She is also upset because her husband has not been back home from work yet. As night was approaching, and almost all the miners returned home, she gradually became angry for she believed that her husband must have gone to the pub again. Then she went to search for her husband. Tension builds as she asked her neighbors for the news about her husband's whereabouts, and Mr. Riley went to search of his missing partner. Everyone knew that Mr. Bates may simply be drunk in a village pub, or may be seriously injured, though they did not speak out their fears. When Walter's mother came to comfort Elizabeth, at Mr. Rigby's suggestion, something is amiss and soon the disaster is revealed. The men from the mine arrive with Walter's body, and at that time, Elizabeth knew for certain that he died. She showed almost more concern for her carpet and a smashed vase than she did for the body of her husband, but she went and kindly comforted her daughter woken by the sounds in the house. After the men left, depositing the body in the parlor, but safely away from the carpet, Elizabeth Bates and her mother-inlaw began to wash the body. Rinsing the dirt from the unmarked body, Elizabeth came to reevaluate her husband.

Elizabeth Bates in The Odour of Chrysanthemums is at the same time in the role of woman, mother, daughter, wife, daughter in law, and at the end of the story a widow. In each of these roles her degree of personal and social ability to influence shifts, as it does anyway in the changing events of the story.

H.M.Daleski, The Forked Flame (London: Faber and Faber, 1965), 443.
As a mother, she cares her children, even when her husband was dead. As a daughter, she cares about her father's life. While as a wife, she is indifferent to her husband for he has disappointed her so much. And even when her husband was dead, and carried by his coworkers, at that moment she seems to care more about the other things than her husband.

It is obvious that Mr. and Mrs. Bates didn't have a harmonious marriage. Mr. Bate cares more about himself rather than his family. And Mrs. Bates is a little bit disappointed with her husband. But instead of giving up, she still tempted to change her husband.

Elizabeth Bates and other characters created before the war are the typical representatives of the female characters in Lawrence's early fictions. They struggle to fight with their husbands or partners and try to occupy the leading position both in their family and in their bisexual relationship. "They try to realize their own value through the dominance and procession of their husband and children." ${ }^{7}$ Lawrence emphasizes the leading position of women and expresses his dislike of their dominance in a variety of occasions. When talking about the women's breaking the Victorian tradition of male dominance, Lawrence points out how the women show extreme privileges before the man:

Woman was so horrible and clutching, she had such a lust for possession, agreed of selfimportance in love. She wants to have, to control, to be dominant. Everything must be referred back to her, to woman, the Great Mother of Everything, out of whom proceeded everything and to whom everything must finally be rendered up. ${ }^{8}$

From the women images Lawrence created before the war, we can conclude that before the war Lawrence had a negative impression about woman.

\section{WOMEN IMAGES DURING THE WAR}

The second stage of Lawrence's art creation is from 1912 to 1917, during which The First World War broke out. Many famous short stories such as "Tickets, Please", "The Blind Man", "Monkey Nuts", "Wintry Peacock", "You Touched Me", "Samson and Delilah", "The Primrose Path", "The Horse Dealer's Daughter" and "Fanny and Annie" were produced. "Tickets, Please" is regarded as a typical

\footnotetext{
7 Zhou Yanfang, Zhang Jianjia, On the Controlling Women of D. H. Lawrence, Journal of Xiangtan Teachers' College (social science edition), 2006/9, Vol.28, No.5.)

D.H. Lawrence, Women in Love (Leicestershire: F.A.
} Thorpe Publishing Ltd., 1982), 312. 
works during the war. And the independent women images Lawrence created in those short stories indicate women's living status is different from that before The First World War.

The wartime is a very crucial transitional period in the development of Lawrence's attitude towards woman. In this stage, influenced by the feminist movement and his marriage to Frieda, the women images in Lawrence's works are independent both in economy and in spirit. They became to search for the female values in the new role as both an individual and a partner in their relationship with the males.

The First World War is the turning point in feminist movement. Because of the war, women have chances to walk out of their home, and take over the responsibility of material production. Then they get paid and get economical independence. After getting some recognition in the society, women tend to get more. They tended to ask not only the job opportunities but also the suffrage in politics and the economic equality with men. And during the war Lawrence espoused feminism to some extent. At the end of 1912, he wrote from Italy to a feminist friend in Eastwood "I shall do my work for women, better than the suffrage."

Lawrence didn't join the war, so he witnessed the social revolution, watching women become much more independent and powerful during the war and their role changing from domestic to individualistic. Much of his works during this period indicates these changes. In the short stories, the heroines are those who pursue independent and have more idea about self-realization. "Tickets, Please" are among those ones, and the heroine of this story Annie Stone is regarded as a representative in this period.

"Tickets, Please" illustrates the phenomenon of women taking the place of men in the work force during war time. In this story the girls fight back from the treatment they receive as well as from the emotional and social circumstances of the war.

In "Tickets, Please" there are two main characters, they are John Thomas and Annie. Annie works on the trams and girls are only chosen to work on the trams for they have a confidant nature and a certain no-nonsense approach to men. And this affects her relationship with John Thomas. Annie and John Thomas are attracted to each other. After the Statutes fair, Annie is rapidly forgetting that she has a boyfriend and is becoming ensnared

Diana Trilling, The Portable D. H. Lawrence (Tennessee: Kingsport Press, 1977), 560. in John Thomas's ploy. They fell in love with each other. However, at that moment John Thomas escaped when Annie tried to know more about his private life and played with other girls. In the end Annie decided to get her own back on John Thomas for rejecting her and she went around her workplace subtle suggesting to the other girls that he had dumped that it would be a good idea to get their revenge on him. At the end, John Thomas fell in the trap organized by Annie and other girls, he is completely humiliated by the girls. And Annie got what she wants.

In the story, Annie Stone is a conductor on a bus during the wartime, when men were all on the battlefield. She was capable enough to fight with the miners on the bus. She appears as a "New Woman" - independent, relatively sexually liberated, oriented more toward productive life in the public sphere than toward reproductive life at home.

Man and woman are equal in her eyes, so when she was discarded by John Thomas, she decided to take revenge on him. She went around the workplace and persuaded other girls do with her. She knew what she wants and how to get it. She was responsible for herself.

Women images created during the war are "emancipated, educated and intelligent; they are stimulating companions and are often crucial in the spiritual development of the men with whom they are involved." 10

Women became individual, self-responsible, taking their own initiative in this period. Living in a society in which education and social moral are ready to accept the young ladies, they are denoted much more chance and possible to get rid of the social restrictions and become a free soul. Faced with a more open society, women are comparatively easier to get self-fulfillment as independent women. The social situation provides a good condition for them to realize their aspiration and pursuit.

\section{WOMEN IMAGES AFTER THE WAR}

The third stage of Lawrence's literary creation is from the ending of The First World War to the death of Lawrence. In this period, Lawrence created lots of world-famous works including The Princess, The Horse Running Winner, The Woman Who Rode Away, The Virgin and The Gipsy and Love among The Haystacks. Among those works there is a

10 David Mitchell, Women on the Warpath (London: Jonathan Cape, 1996), 47. 
common thing Lawrence wants to express, that is what women want and how they can get it. The Woman Who Rode Away is a short story Lawrence wrote after the war, in which readers may find the answer.

After the First World War, a new world emerged. Large numbers of women found a place in the labor force, doing new jobs at men's rates of pay, with new expectations, including a new sense of sexual freedom. But this is not the ideal women in Lawrence's eyes. The feminism movement goes too far, he felt a sense of threat. He believed that the dominant ideology of the post war world feminine is not a true femininity of instinct and feeling, but a perverted femininity of will and idealism. He asserted that women had become the dominant sex and even suggested programs for masculine revolution.

In Lawrence's late work, and in the popular literature, the independence of women is the given starting-point, not the goal. "The novels revolve around the question of what use women shall make of their freedom. The implied answer, in most case, is that they will find fulfillment by voluntarily relinquishing it, and consigning themselves to the man who will satisfy their essentially masochistic sexual needs." ${ }^{11}$

The heroine in the story is a lady of thirty-three, she married a man, twenty years older than her. Her husband is a rich mine owner, who loved her very much. However, he is so concerned about her that treated her like a private property. He didn't allow other men even his friends to get close to his wife. The woman was under the control of her husband. Although she is rich, she has no freedom. And as her husband is too old for her, their marriage is inharmonious. The heroine was not satisfied with her husband and their family, "she wanted to have a look at the things behind the mountains"12, where Indians lived there. So, one day, when her husband was not at home, she rode away towards the mountains. She rode away in order to search the harmonious relationship between man and woman. She was tired with the God of white people and wanted to look for the Indian's God. And finally she sacrificed herself for the Indian's God.

Women images created by Lawrence after the war are characterized by new qualities. "They were optimistic, hopeful, honest and courageous, against

\footnotetext{
11 Hilary Simpson, D. H. Lawrence and Feminism (London: Croom Helm London \& Canberra, 1982), 123.

12 Neil Myers, Lawrence and the War (London: Victor Gllancz, 1933) 405.
}

all kinds of social restrictions and conventions." ${ }^{13}$ They found self-fulfillment with men in nature and wanted to get united with men both physically and spiritually, and went to explore the unknown world together with them.

According to Lawrence, women can only find who they are and where to go in nature. From nature human being comes from and to nature he will go. So, nature is the final god of women's aspiration and pursuit.

\section{CONCLUSION}

After study many important women images in Lawrence's short stories, from the powerful Elizabeth Bates, independent Annie Stone to the self-reliant white woman, we can find that women images in Lawrence's short stories are different. This actually indicates that in different periods Lawrence's attitude towards woman are different.

The changing process is a gradual process. From an enthusiastic suffrage supporter, to a profound thinker in feminism, and to an advocate for true femininity, Lawrence finishes his transformation as a great writer. From a mother of power, to a girlfriend of independence, and to a wife of instinct, Lawrence changes his view on women with the development of the feminism movement.

With the development of feminism movement, the roles women take place in the society changed. They became more independent both economically and spiritually. Lawrence's works may to some extend reflect those changes in reality. But it also indicates Lawrence's attitude towards woman in different periods

\section{References}

[1] Daleski. H.M. The Foeked Flame. London: Faber and Faber, 1965

[2] Dix, Carol. D.H. Lawrence and Women. London: Macmillan Press, 1980

[3] Lawrence. D.H. The Complete short stories. England: Penuin Books, 1961

[4] Lawrence. D.H. Women In Love . Leicestershire: F.A. Thorpe Publishing Ltd.,1982

[5] Mitchell, David .Women on the Warpath. London: Jonathan Cape, 1996

[6] Murry, John Middleton. Son of Woman. London: Jonathan Cape, 1931

[7] Myers, Neil. Lawrence and the War. London: Victor Gllancz, 1933

13 D.H.Lawrence, The Complete short stories (England: Penguin Books, 1961), 108. 
[8] Nin, Anais. D.H.Lawrence: An Unprofessinal Study .Paris: Edward W.Titus, 1932

[9] Simpson,Hilary. D.H.Lawrence and Feminism. London: Croom Helm London \& Canberra, 1982

[10] Trilling, Diana. The Portable D.H.Lawrence. Tennessee: Kingsport Press, 1977

[11] Keith Saag, Lawrence's Life, Trans, Gao Wanlong \& Wangjianqi, Jinan: Shandong Friendship Books, 1989.)

[12] Zhou Yanfang, Zhang Jianjia, On the Controlling Women of D. H. Lawrence, Journal of Xiangtan Teachers' College (social science edition), 2006/9, Vol.28, No.5.) 